\title{
Extraction, Purification and Characterization of Endo-Acting Pullulanase Type I from White Edible Mushrooms
}

\author{
Abeer N Shehata $^{1 *}$, Doaa A Darwish ${ }^{2}$, Hassan MM Masoud ${ }^{2}$ \\ ${ }^{1}$ Biochemistry Department, National Research Centre, Dokki, Giza, Egypt. ${ }^{2}$ Molecular Biology Department, National Research Centre, Dokki, Giza, Egypt.
}

\begin{tabular}{|c|c|}
\hline ARTICLE INFO & ABSTRACT \\
\hline Article history: & \multirow{9}{*}{$\begin{array}{l}\text { Pullulanase (EC 3.2.1.41) has been isolated and purified from white edible mushrooms by ammonium sulphate } \\
\text { precipitation (20-70\%) followed by ion exchange chromatography (DEAE-cellulose) and gel filtration (Sephadex } \\
\mathrm{G} 75-120 \text { ), with final yield ( } 20 \% \text { ) and purification fold (17.8). The molecular mass of pullulanase enzyme was } \\
112 \mathrm{kDa} \text { as estimated by SDS-PAGE and the } \mathrm{pI} \text { value was } 6.2 \text {. The apparent } \mathrm{K}_{\mathrm{m}} \text { and } \mathrm{V}_{\text {max }} \text { values for purified } \\
\text { pullulanse on pulluan were } 0.27 \mathrm{mM} \text { and } 0.74 \mu \mathrm{M} \mathrm{min}{ }^{-1} \text { respectively. The activity was optimum at } 40^{\circ} \mathrm{C} \text { and } \mathrm{pH} \\
6 \text {. Pullulanase showed moderate thermo-stability. A relative substrate specificity for hydrolysis of soluble starch, } \\
\text { amylopectin and glycogen was } 80,60 \text { and } 30 \% \text { respectively. Enzyme activity was highly activated by } \mathrm{Fe}^{+2}, \mathrm{Mn}^{+2} \\
\text { and } \mathrm{Ca}^{+2} \text { ions, while the activity was inhibited by } \mathrm{Hg}^{+2} \text { and } \mathrm{Ag}^{+} \text {ions. Ethylenediaminetetraacetic acid (EDTA) } \\
\text { and Dithiothreitol (DTT) were activated the enzyme activity. On contarary iodoacetate and sodium fluoride were } \\
\text { inhibited the activity. HPTLC (High Performance Thin Layer Chromatography) plate showed that the purified } \\
\text { pullulanase caused the complete hydrolysis of pullulan to maltotriose. }\end{array}$} \\
\hline Received on: 09/10/2015 & \\
\hline Revised on: 07/11/2015 & \\
\hline Accepted on: 22/11/2015 & \\
\hline Available online: $26 / 01 / 2016$ & \\
\hline Key words: & \\
\hline Pullulanase, White edible & \\
\hline mushrooms, Purification, & \\
\hline Characterization, HPTLC & \\
\hline
\end{tabular}

\section{INTRODUCTION}

Pullulan is a polymer synthesized by the yeast-like fungus Aureobasidium pullulans. It is a linear $\alpha$-D-glucan built of maltotriose subunits (Abdullah and French 1966). Pullulanase, It belongs to the $\alpha$-amylase family, which is identified as glycoside hydrolase and break $\alpha-1,6$ linkages in pullulan, starch, amylopectin and related oligosaccharides (Duan and Wu, 2015). Pullulanases are classified into five types based on the substrate specificity (Roy et al., 2003; Haki and Rakshit, 2003). (1) the glucoamylase type is an exo-acting carbohydrase (Reilly, 1979), which hydrolyzes pullulan from non-reducing ends to produce glucose; (2) the pullulanase type I specifically hydrolyses $\alpha-1,6$ glycosidic linkages in pullulan or branched substrates such as amylopectin forming maltotriose (3) the isopullulanase type from Aspergillus niger, which hydrolyzes $\alpha-1,4$ linkages of pullulan to produce isopanose; and (4) Pullulan hydrolase type I (neopullulanase) from Bacillus stearothermophilus (Ecel et al., 2015) which hydrolyzes $\alpha-1,4$ linkages of pullulan to produce panose. (5) pullulanase type II (amylopullulanase) attacks $\alpha-1,6$ linkages in pullulan and branched substrates in addition to $\alpha-1,4$ links in polysaccharides other than pullulan (Bertoldo and

* Corresponding Author

E-mail: futtur@yahoo.com,

Tel: (+202) 3337362. Fax: (+202) 3337693.
Antranikian, 2002; Duffner et al., 2002). Pullulanases belong to group of glycosylhydrolases that are widely distributed in nature and are produced by an extremely wide variety of species such as animals, plants and microorganisms (Hyun and Zeikus, 1985; Zhang et al., 2013; Duan and Wu, 2015). Pulluanases have gained important in current saccharification processes as starchdebranching enzymes. In the starch processing industry for the production of maltose syrups and high purity glucose and fructose (Jensen and Norman 1984). This occurs when pullulanase is used in combination with glucoamylase or $\alpha$-amylase, respectively in the saccharification process. Pullulanases that specifically attack the branching points of amylopectin are of special interest. The action of such enzymes would lead to the formation of linear oligosaccharides that can be attacked efficiently by other amylolytic enzymes, leading to high levels of glucose or maltose. Pullulanases are used in detergent industry as effective additives in dish washing and laundry detergents for the removal of starches under alkaline conditions (Van and Willem 1990) and in the manufacturing of low caloric beer (Olsen et al., 2000). It is also possible to use pullulanase as a dental plaque control agent (Marotta et al., 2002). Because of the various importance uses of pullulanase, it has been the subject of various applications so, the present study was conducted to extract, purify and characterize a highly active pullulanase from white edible mushrooms. 


\section{MATERIALS AND METHODS}

\section{Materials}

White edible mushrooms were purchased from local market. Diethylaminoethyl-cellulose (DEAE-cellulose) and molecular weight marker kits were purchased from Sigma Company while Sephadex 75-120, pullulan, maltose, amylopectin, glycogen, dextrin, soluble starch, EDTA, DTT and maltooligosaccharides $\left(\mathrm{G}_{6}-\mathrm{G}_{3}\right)$ from Fluka chemical Co., all other chemicals were of analytical grade.

\section{Methods}

\section{Preparation and extraction of crude enzyme}

Mushrooms were extracted by distilled water at $9^{\circ} \mathrm{C}$ with continuous shaking over a period of $2 \mathrm{~h}$. This extract was then centrifuged at $3000 \mathrm{rpm}$ for $15 \mathrm{~min}$, and the supernatant was collected, dialyzed against distilled water and then used as the crude enzyme preparation.

\section{Purification of pullulanase enzyme 1) Ammonium sulfate precipitation}

The crude extract was brought to $20-70 \%$ saturation by gradually adding solid $\left(\mathrm{NH}_{4}\right)_{2} \mathrm{SO}_{4}$ and stirred for $30 \mathrm{~min}$ at $4{ }^{\circ} \mathrm{C}$. The pellet was obtained by centrifugation at $12000 \times \mathrm{g}$ for $30 \mathrm{~min}$ and dissolved in $0.02 \mathrm{M}$ sodium phosphate buffer $\mathrm{pH} 6$ and dialyzed extensively against the same buffer.

\section{2) DEAE-cellulose column chromatography}

The dialyzed sample was chromatographed on a DEAEcellulose column $(12 \times 2.4 \mathrm{~cm}$ i.d.) previously equilibrated with $0.02 \mathrm{M}$ sodium phosphate buffer $\mathrm{pH}$ 6. The adsorbed proteins were eluted firstly with sodium phosphate buffer $(0.02 \mathrm{M}-\mathrm{pH} 6)$ then with a stepwise $\mathrm{NaCl}$ gradient ranging from 0.05 to $0.5 \mathrm{M}$ prepared in the equilibration buffer at a flow rate of $60 \mathrm{ml} /$ hour. $5 \mathrm{ml}$ fractions were collected and the fractions containing pullulanase activity were pooled and lyophilized.

\section{3) Sephadex G 75-120 column Chromatography}

The concentrated solution containing the pullulanase activity was applied onto a Sephadex G75-120 column $(40 \mathrm{~cm}$ x $1.8 \mathrm{~cm}$ i.d.). The column was equilibrated and developed with 0.02 $\mathrm{M}$ sodium phosphate buffer $\mathrm{pH} 6$ at a flow rate of $30 \mathrm{ml} / \mathrm{hour}$ and $2 \mathrm{ml}$ fractions were collected.

\section{Enzyme assay}

Pullulanase activity was assayed by measuring the reducing sugar released from pullulan. The reaction mixture $(1 \mathrm{ml})$ containing pullulan $(1 \% \mathrm{w} / \mathrm{v})$ in sodium phosphate buffer $0.02 \mathrm{M}$, $\mathrm{pH} 6$ and enzyme was incubated at $40{ }^{\circ} \mathrm{C}$ for $30 \mathrm{~min}$. The reducing sugar was measured by the dinitrosalicylic acid method (Millar, 1959). One unit of pullulanase activity is defined as the amount of enzyme which produces $1 \mu \mathrm{mol}$ of reducing sugar with glucose as the standard per min under the optimum conditions.

\section{Electrophoretic analysis and isoelectric point}

Native gel electrophoresis was carried out with $7 \%$ PAGE (Smith, 1969). In order to examine the subunit composition of the pullulanase, protein samples were also analyzed by $12 \%$ sodium dodecyl sulfatepolyacrylamide gel electrophoresis (SDSPAGE) as described by Laemmli, 1970 after the samples had been heated at $100{ }^{\circ} \mathrm{C}$ for $5 \mathrm{~min}$. Low-molecular weight marker proteins were used as standards. Following native PAGE and SDS-PAGE the proteins were stained with Coomassie blue (Weber and Osborn, 1969).

The isoelectric point of the pullulanase was determined by isoelectric focusing under native conditions. Electro-focusing was performed according to O'Farrell, (1975) and the isoelectric point $(p \mathrm{I})$ value was calculated from a calibration curve (Ubuka et al., 1987). The proteins were stained with $0.25 \%$ Coomassie brilliant blue R-250.

\section{Protein determination}

Protein was determined by the dye binding assay method of Bradford (1976) using Bovine serum albumin (BSA) as a standard protein.

\section{Biochemical characterization of the purified enzyme}

\section{Effect of temperature on enzymatic activity and thermal stability}

To determine the temperature effect on the enzyme activity the reaction mixture containing pullulan and purified pullulanase were incubated at different temperatures for $30 \mathrm{~min}$ and the activity was assayed. Thermal stability was determined by incubating the enzyme samples in different temperatures at different time intervals.

\section{Effect of $\mathbf{p H}$ on pullulanase activity}

To $0.5 \mathrm{ml}$ of $1 \%(\mathrm{w} / \mathrm{v})$ of pullulan in various $\mathrm{pH}$ 's (4-8) at $0.02 \mathrm{M}$ concentration, $0.5 \mathrm{ml}$ of the purified pullulanase was added for $30 \mathrm{~min}$ at $40^{\circ} \mathrm{C}$.

\section{Substrate specificity}

The ability of the purified enzyme to hydrolyze various carbohydrates was examined at $40{ }^{\circ} \mathrm{C}$ and $\mathrm{pH} 6$ in 0.02 sodium phosphate buffer. The carbohydrates tested were pullulan, amylopectin, soluble starch, glycogen and dextrin at a concentration $1 \%(\mathrm{w} / \mathrm{v})$.

\section{Effect of metal ions and chelating agents on the activity of pullulanase}

The purified pullulanase was preincubated with various metal ions at $0.1 \mathrm{M}$ concentration and chelating agents at $1 \mathrm{M}$ concentration.

The purified treated enzyme was incubated at $40^{\circ} \mathrm{C}$ for $30 \mathrm{~min}$ in $0.02 \mathrm{M}$ sodium phosphate buffer, $\mathrm{pH}$ 6. The enzyme sample without any additives was considered as control. 


\section{Kinetic determination}

Michaelis-Menten constant $\left(\mathrm{K}_{\mathrm{m}}\right)$ and maximum velocity $\left(\mathrm{V}_{\max }\right)$ of pullulanase were estimated according to Lineweaver and Bark, 1934 using different concentration of pullulan.

\section{End product analysis}

Purified pullulanase samples were added to pullulan at a concentration of $1 \%(\mathrm{w} / \mathrm{v})$ in $0.02 \mathrm{M}$ sodium phosphate buffer, at $\mathrm{pH}$ 6. The reaction mixtures were incubated at $40^{\circ} \mathrm{C}$ for 1,2 and 24 hours. The products were analyzed by HPTLC plate with malto-oligosaccharide $\left(\mathrm{G}_{3}-\mathrm{G}_{6}\right)$, maltose and glucose used as standards. Chromatography was carried out using the solvent system, Butanol: acetic acid: water (40:10:50 v/v/v). Carbohydrates were detected by staining with anilinediphenylamine phosphoric acid reagent. The enzymatic products was visualized as blue spots after incubating the plate at $70^{\circ} \mathrm{C}$ for 5 min (Asha et al., 2013).

\section{RESULT AND DISCUSSION}

\section{Purification of pullulanase enzyme from mushroom.}

A typical purification scheme of pullulanase from the mushroom is presented in Table (1). The purification procedure was carried out by ammonium sulfate precipitation (20-70\%) followed by ion exchange chromatography on DEAE-cellulose column and gel filtration chromatography on Sephadex G75-120 column. The specific activity of the pullulanase of mushrooms crude extract was found to be 10 units/mg protein. Similar purification procedure of pullulanase was reported from the fungus Hypocrea jecorina (Orhan et al., 2014).

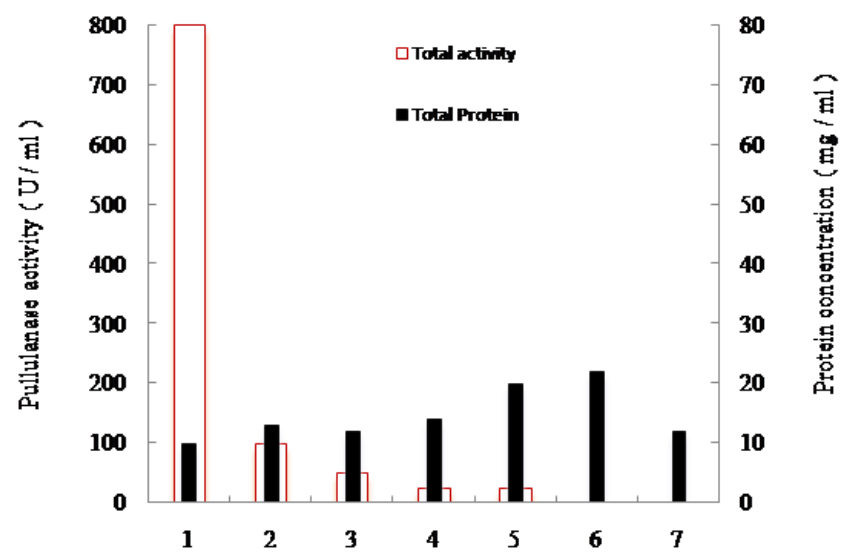

Fig. 1: Measurment of pullulanase activity and protein content that eluated from DEAE-cellulose using 1-)0.02M sodium phosphate buffer and (2-7) 0.05$0.5 \mathrm{M} \mathrm{NaCl}$ in sodium phospate (pH6.0, 0.02M).

The DEAE-cellulose elution profile (Figure 1) revealed the presence of one peak containing pullulanase activity eluted with $0.02 \mathrm{M}$ sodium phosphate buffer $\mathrm{pH}$ 6. The DEAE-cellulose fraction of this peak were pooled, concentrated by lyophilization and applied onto a Sephadex G75-120 column (Figure 2) which revealed the presence of one peak of pullulanase enzyme activity. The pullulanase was purified with a specific activity of 97 units/ mg protein and 17.8 purification fold with $20 \%$ yield (Table 1).
Different purification fold and recovery percent values of pullulanase were reported, pullulanase from the fungus Hypocrea jecorina was purified 11 folds with $10.1 \%$ yield (Orhan et al., 2014). Purification fold of pullulanase from Bacillus subtilis was 24 with $75 \%$ yield (Asoodeha and Lagziana 2012).

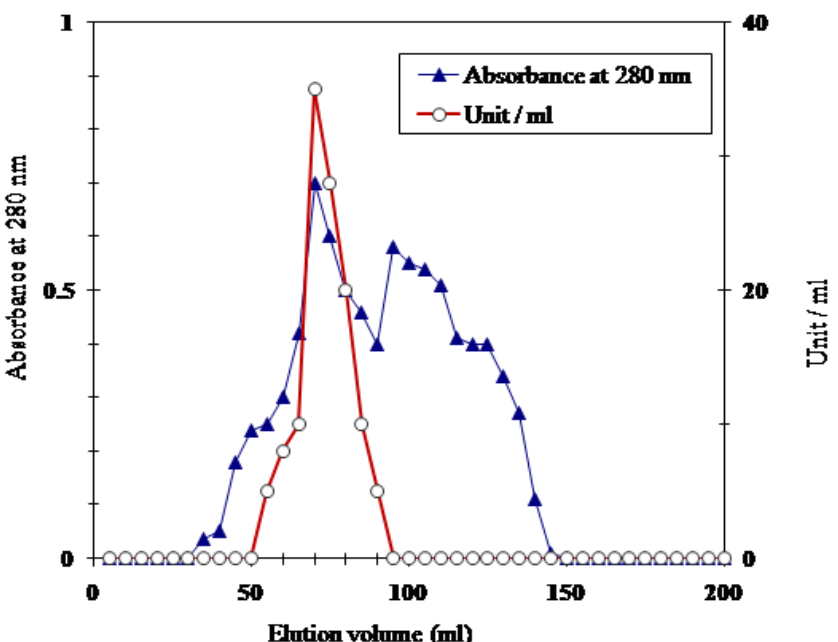

Fig. 2 A typical elution profile for the chromatography of mushroom DEAEcellulose fraction on Sephadex G-75-120 column $(40 \mathrm{~cm} \times 1.8 \mathrm{~cm}$ i.d.) previously equilibrated with $0.02 \mathrm{M}$ sodium phosphate buffer $\mathrm{pH}$ 6.0.

Table 1: Purification table of mushroom pullulanase.

\begin{tabular}{|c|c|c|c|c|c|}
\hline Steps of purifacation & 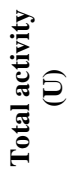 & 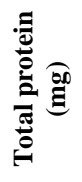 & & 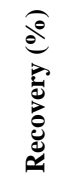 & : \\
\hline Crude Extract & 1600 & 160 & 100 & 100 & 1 \\
\hline $200-70 \%(\mathrm{NH} 4) 2 \mathrm{SO} 4$ & 1272 & 30 & 42.4 & 79.5 & 4.24 \\
\hline $\begin{array}{l}\text { DEAE-cellulose ion- } \\
\text { exchange chromatography }\end{array}$ & 800 & 10 & 80 & 50 & 8 \\
\hline $\begin{array}{l}\text { Sephadex G-75-120 gel } \\
\text { filteration chromatography }\end{array}$ & 175 & 108 & 97 & 20 & 17.8 \\
\hline
\end{tabular}

Electrophoretic analysis and isoelectric point of the purified pullulanase

The purity of pullulanase was investigated by electrophoretic analysis. Samples from crude extract, DEAE-cellulose and Sephadex G75-120 fractions of pullulanase were analyzed electrophoretically on $7 \%$ native PAGE (Figure 3 ).

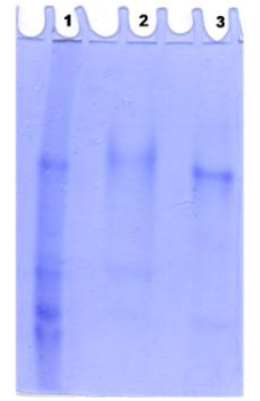

Fig. 3: Electrophoretic analysis of pulluamase on 7\% native PAGE: (1) Mushroom crude extract (2) DEAE-cellulose fraction, (3) Sephadex G-75-120 fraction. 
Single protein band of the purified pullulanase was obtained indicating the tentative purity of the preparation. The molecular mass of the purified pullulanase enzyme was determined by SDSPAGE to be $112 \mathrm{kDa}$ (Figure 4). Different molecular masses were reported; pullulanase from Bacillus sp. has a molecular mass of $106 \mathrm{kDa}$ in consistent with our preparation (Kunamneni and Singh, 2006). Pullulanase from the fungus Hypocrea jecorina has a molecular mass of $136 \mathrm{kDa}$ (Orhan et al., 2014). Pullulanase from bacterium Fervidobacterium pennavorans has a molecular mass of $240 \mathrm{kDa}$ (Koch et al., 1997). The native protein exhibited $p \mathrm{I}$ of 6.2 (Figure 5). This is consistent with the isoelectric point ( $p \mathrm{I})$ value of pullulanase from Bacillus subtilis which was around $\mathrm{pH} 6$ (Asoodeha and Lagziana, 2012).

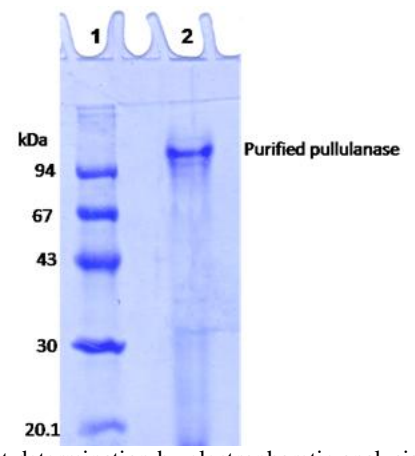

Fig. 4: Molecular weight determination by electrophoretic analysis analysis on $12 \%$ SDSPAGE: (1) molecular weight marker proteins and (2) purified pullulanase.

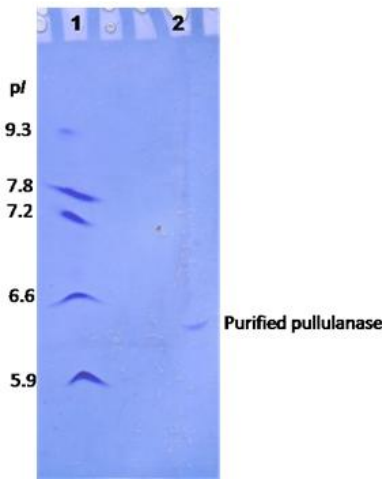

Fig. 5 Isoelectro focusing: (1) Isoelectric point (pl) marker proteins, (2) the pufified pullulanase.

\section{Biochemical characterization of the purified enzyme}

\section{Effect of temperature on the activity and thermal stability of purified pullulanase}

The maximum activity was observed at $40^{\circ} \mathrm{C}$ (Figure 6). Thermal stability was studied at different temperatures at different time intervals, purified pullulanase showed moderate stability as the residual activity after 30 min incubation at $60^{\circ} \mathrm{C}$ was $50 \%$, while the residual activity was $20 \%$ after incubation for $45 \mathrm{~min}$ at $70^{\circ} \mathrm{C}$ (Figure7). Asha et al. (2013) showed that the maximum activity of pullulanase from Bacillus halodurans was observed at $50^{\circ} \mathrm{C}$. Thermal stability was studied at $50^{\circ} \mathrm{C}$ for an extended range of incubation period. Up to $45 \mathrm{~min}$. incubation had less effect on enzyme activity. At $1^{\text {st }}$ hour, $60 \%$ residual activity was observed, $2^{\text {nd }}$ hour $46 \%$ residual activity and at overnight incubation, $17 \%$ residual activity was observed.

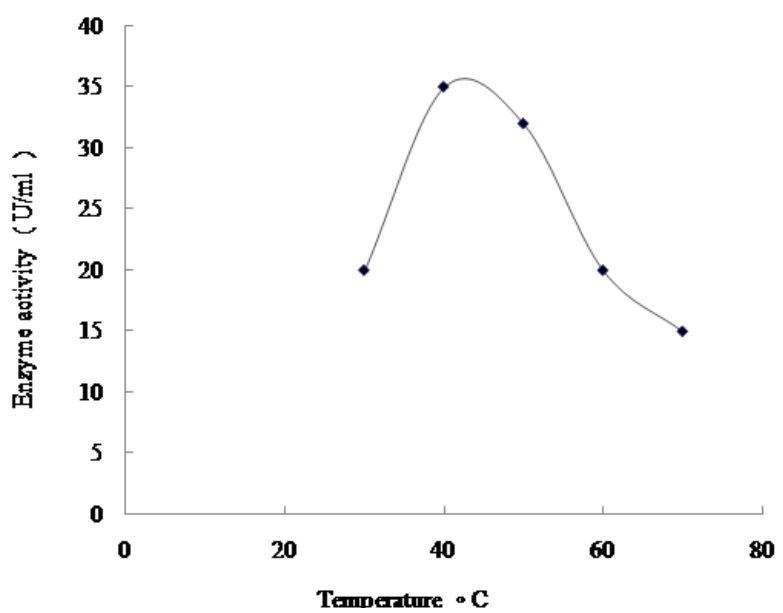

Fig. 6: The effect of different temperatures on pullulanase activity-

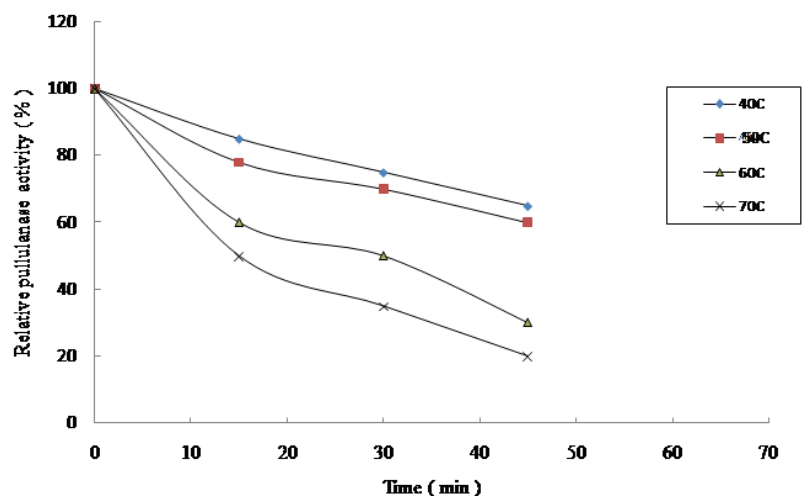

Fig. 7: Thermostability of the pullulanase. The purified enzyme was incubated at different temperatures at different time intervals.

\section{Effect of $\mathrm{pH}$ on pullulanase activity}

As shown in Figure (8) the $\mathrm{pH}$ value at which the pullulanase showed maximum activity was observed at $\mathrm{pH} 6$. The same result was reported by Ling et al., 2009, while Ara et al., 1995 showed that maximum activity was observed at $\mathrm{pH} 9.5$.

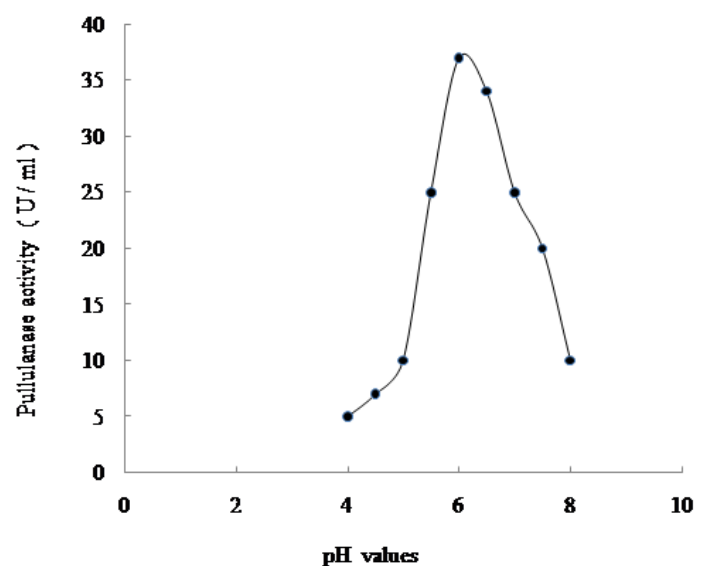

Fig. 8: The effect of different $\mathrm{pH}$ 's on pullulanase activity at $0.02 \mathrm{M}$ concentration of the tested buffers. 


\section{Substrate specificity}

Among all different substrates soluble starch gave high relative enzyme activity (80\%) compared to others, glycogen $(30 \%)$ and dextrin $(10 \%)$ but also there is considerable good activity for amylopectin (60\%) (Table 2). Similarly a pullulanase from Bacillus halodurans showed also a broad substrate specificity with high relative activity towards soluble starch $(90 \%)$ and amylopectin (75\%).

On contrary, Ling et al. (2009) reported that starch, amylopectin and dextran gave low relative enzyme activity 28,20 and $0.2 \%$ respectively.

Table 2: Substrate specificity of pullulanae from edible mushrooms.

\begin{tabular}{lc}
\hline \multicolumn{1}{c}{ Substrate } & Relative activity \\
\hline Pullulan & 100 \\
Soluble starch & 80 \\
Amylopectim & 60 \\
Glycogen (bovine muscle) & 30 \\
dextrin & 10 \\
\hline
\end{tabular}

\section{Effect of metal ions and chelating agents on the activity of pullulanase}

$\mathrm{Hg}^{2+}, \mathrm{Ag}+$ and $\mathrm{Co}^{2+}$ showed strong inhibition on pullulanase activity, while $\mathrm{Mg}^{2+}$ slightly inhibited the enzyme. Almost $\mathrm{Ni}^{2+}, \mathrm{Na}^{+}$and $\mathrm{Cu}^{2+}$ have no effect on the activity. $\mathrm{Fe}^{2+}$, $\mathrm{Mn}^{2+}$ and $\mathrm{Ca}^{2+}$ ions have very strong effect on stimulating the activity of pullulanase (Table 3).

Ara et al., 1995 reported that pullulanase activity of the enzyme was strongly inhibited by $\mathrm{Hg}^{2+}$ and $\mathrm{Mn}^{2+}$. While $\mathrm{Co}^{2+}$ ions slightly stimulated the pullulanase activity.

Table 3: Effect of metals on pullulanase activity.

\begin{tabular}{lcc}
\hline Metals & Concentration(M) & Relative activity(\%) \\
\hline $\mathrm{NiCl}_{2}$ & 0.1 & 105 \\
$\mathrm{CoCl}_{2}$ & 0.1 & 40 \\
$\mathrm{MnCl}_{2}$ & 0.1 & 150 \\
$\mathrm{MgCl}_{2}$ & 0.1 & 70 \\
$\mathrm{Nacl}_{\mathrm{FeCl}}$ & 0.1 & 100 \\
$\mathrm{CuCl}_{2}$ & 0.1 & 160 \\
$\mathrm{CuCl}_{2}$ & 0.1 & 100 \\
$\mathrm{AgNO}_{3}$ & 0.1 & 140 \\
$\mathrm{HgCl}_{2}$ & 0.1 & 50 \\
\hline
\end{tabular}

Table 4: Effect of chelating agents on pullulanase activity.

\begin{tabular}{lcc}
\hline Activators and inhibitor & Concentration(M) & Relative activity(\%) \\
\hline EDTA & 1 & 130 \\
Mercaptoethanol & 1 & 100 \\
Iodoacetate & 1 & 90 \\
DTT & 1 & 110 \\
Sodium fluoride & 1 & 90 \\
\hline
\end{tabular}

Table (4) Showed that EDTA and DTT stimulate the activity of pullulanase while iodoacetate and sodium floride slightly inhibited the enzyme activity, while mercaptoethanol has no effect. Ara et al. (1995) showed that monoiodoacetate had moderately inhibitory effect on the enzymatic activity, while Asha et al. (2013) reported that EDTA and DTT did not obviously inhibit the pullulanase activity.

\section{Kinetic properties of pullulanase}

The activity of pullulanase from mushrooms on pullulan as a substrate showed Michaelis-Menten Kinetics. The apparent Michaelis-Menten constant $\left(\mathrm{K}_{\mathrm{m}}\right)$ value for pullulan was $0.27 \mathrm{mM}$, while the value of $V_{\max }$ was $0.74 \mu \mathrm{mol} \mathrm{min}{ }^{-1}$ (Fig. 9). The $K_{m}$ of pullulanase type II from Bacillus cereus $\mathrm{H} 1.5$ was $1.1 \mathrm{mg} \mathrm{mL}^{-1}$, while the value of $\mathrm{V}_{\max }$ was $0.275 \mu \mathrm{mol} \mathrm{min}{ }^{-1}$ (ling et al., 2009).

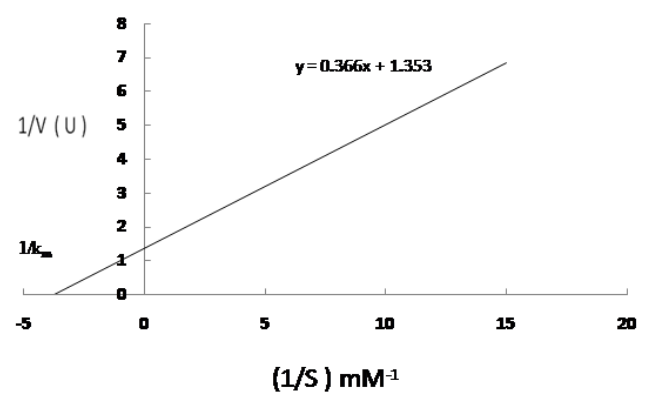

Fig. 9: Lineweaver- burk plot for pullulam hydrolysis by mushroom pullulanase. The assay was conducted in $0.02 \mathrm{M}$ phosphate buffer at $40^{\circ} \mathrm{C}$.

\section{End products of pullulanase action}

Maltotriose was the only trimeric (degree of polymerization, DP3), product of pullulan hydrolysis after incubation at 1,2 and 24 hours (Figure 10), indicating that the enzyme hydrolysis is specific for $\alpha-1-6$ glucosidic linkage of pullulan and the enzyme is endo - acting enzyme and belong to type I pullulanase.

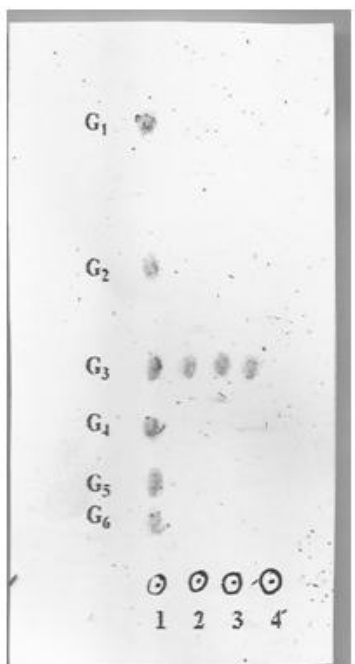

Fig. 10: Analysis of end products of pullulanase with pullulam by HPTLC technique. Lane 1 represent malto-oligosacharide standards $\left(\mathrm{G}_{6}-\mathrm{G}_{3}\right)$ maltose $\left(G_{2}\right)$ and glucose $\left(G_{1}\right)$ lane (2-4) represent the end products at 1,2 and 24 hours incubation respectively.

\section{CONCLUSION}

Pullulanase type I produced by edible white mushrooms was capable to attack specifically $\alpha-1,6$ linkages in pullulan to generate maltotriose as the major end product. Pullulanase is moderately stable at the high temperature range. Current research work is focused on the extraction, purification and characterization 
of an industrial enzyme such as pullulanase by very simple and inexpensive methods from white edible mushrooms which are considered very safe source in food industry. Pullulanases have wide scale application in pullulan processing industry on account of their thermo-stability and ability to degrade row pullulan. The high substrate specificity of pullulanase together with its thermal stability makes this enzyme a good selection in the starchprocessing and detergent industries and other biotechnological applications.

\section{REFERENCES}

Abdullah M, French D. Reverse action of pullulanase. Nature, 1966; 200:210

Ara K, Saeki K, Igarashi K, Takaiwa M, Uemura T, Hagihara $\mathrm{H}$, Kawai S, Ito S. Purification and characterization of an alkaline amylopullulanase with both $\alpha-1,4$ anId $\alpha-1,6$ hydrolytic activity from alkalophilic Bacillus sp. KSM-1378. Biochim Biophys Acta, 1995; 1243:315-324

Asha R, Niyonzima FN, Sunil SM. Purification and Properties of Pullulanase from Bacillus halodurans. Int. Res. J. Biological Sci, 2013; 2(3):35-43.

Asoodeha A, Lagziana M. Purification and characterization of a new glucoamylopullulanase from thermotolerant alkaliphilic Bacillus subtilis DR8806 of a hot mineral spring. Process Biochem, 2012; 47: 806815.

Bertoldo C, Antranikian G. Starch hydrolyzing enzymes from thermophilic archaea and bacteria. Curr Opin Chem Biol, 2002; 6:151160. DOI: 10.1016/S1367-5931(02)00311-3.

Bradford MM. A rapid and sensitive method for the quantitation of microgram quantities of protein utilizing the principle of protein-dye binding. Anal Biochem, 1976; 72: 248-254.

Duan X, Wu J. Enhancing the secretion 1 efficiency and thermostability of Bacillus deramificans pullulanase mutant $\mathrm{D} 437 \mathrm{H} /$ D503Y by N-terminal domain truncation Appl Environ Microbiol, 2015; 81(6):1926-31 doi:10.1128/AEM.03714-14.

Duffner FC, Bertoldo JT, Andersen KW, Antranikian GA. New thermoactive pullulanase from Desulfurococcus mисоsus: Cloning, sequencing, purification and characterization of the recombinant enzyme after expression in Bacillus subtilis. J. Bacteriol, 2002; 182: 6331-6338.

Ece1 S, Evran S, Janda J, Merkl R. Improving thermal and detergent stability of Bacillus stearothermophilus neopullulanase by rational enzyme design, 2015;28(6):147-51.doi: 10.1093/protein/gzv001.

Haki GD, Rakshit SK. Developments in industrially important thermostable enzymes: A review. Bioresour. Technol, 2003; 89: 17-34. DOI: $10.1016 / \mathrm{S} 0960-8524(03) 00033-6$.

Hyun HH, Zeikus JG. General biochemical characterization of thermostable pullulanase and glucoamylase from Clostridium thermohydrosulfurium, Appl. Environ. Microbial, 1985; 49: 1168-1173.

Jensen BD, Norman BE. Bacillus acidopullyticus pullulanase: applications and regulatory aspects for use in food industry, Proc Biochem, 1984; 1:397-400.

Koch R, Canganella F, Hippe H, Jahnke KD, Antranikian. Purification and properties of a thermostable pullulanase from a newly isolated thermophilic anaerobic bacterium, Fervidobacterium pennavorans Ven5. Appl Environ Microbiol, 1997; 63: 1088-1094.

Kunamneni A, Singh S. Improved high thermal stability of pullulanase from a newly isolated thermophilic Bacillus sp. AN-7. Enzyme Microb Tech, 2006; 39: 1399-1404.
Laemmli UK. Cleavage of structural proteins during the assembly of the head of Bacteriophage T4. Nature, 1970; 227: 680-685.

Lineweaver H, Burk D. The determination of enzyme dissociation constants, J. Am. Chem. Soc, 1934; 56:658-666.

Ling HS, Ling TC, Mohamad R, Ariff BA. Characterization of Pullulanase Type II from Bacillus cereus H1.5. Am J Biochem Biotech, 2009; 5 (4): 170-179.

Marotta M, Martino A, De Rosa A, Farina E, Carteni M, De Rosa M, Degradation of dental plaque glucans and prevention of glucan formation using commercial enzymes, Proc. Biochem, 2002; 38(1)1:01108.

Miller GL. Use of dinitrosalicylic agent for determination of reducing sugars, Anal. Chem, 1959; 31:426-428.

O'Farrell PH. High resolution two-dimentional electrophoresis of proteins. J Biol Chem, 1975; 250: 4007 - 4021.

Olsen HS, Goddard P, Nordisk AS. 2000. In Novo Nordisk A/S, 58.

Orhan N, Kiymaz NA, Peksel A. A novel pullulanase from a fungus Hypocrea jecorina QM9414: production and biochemical characterization. Indian J Biochem Biophys, 2014; 51: 149-155.

Reilly PJ. Starch hydrolysis with soluble immobilized glucoamylase. In L. B. Wingard. E. Katchalski- Katzir. and L. Goldstein (ed.). Appl Biochem Biotech, 1979 vol.2 p.185-205. enzyme technology. Academic Press, Inc., New York.

Roy A, Messaoud EB , Bejar S. Isolation and purification of an acidic pullulanase type II from newly isolated Bacillus sp. US149. Enz. Microb. Technol, 2003; 33:720-724. DOI: 10.1016/S0141-0229(03) 00212-6

Smith I. 1969. Acrylamide gel disc electrophoresis. In: Smith, I., (Eds.), Electrophoretic techniques, Academic press, New York, pp. 365-515

Ubuka T, Masuoka N, Yoshida S, and Ishino K. Determination of isoelectric point value of 3-Mercaptopyruvate sulfurtransferase by isoelectric focusing using ribonuclease A-glutathione mixed disulfides as standards. Anal Biochem, 1987;167: 284-289.

Van D, Willem R. Dishwashing detergents containing enzyme capable of breaking $\alpha$-1,6-glucoside linkage, Brit. UK Patent Appl, 1990; GB2, 228, 945

Weber K, Osborn M. The reliability of molecular weight determinations by dodecyl sulfate-polyacrylamide gel electrophoresis. J Biol Chem, 1969; 244: 4406-4412.

Zhang Y, Liu Yh, Li Y, Liu Xg, Lu FP. Extracellular expression of pullulanase from 354 Bacillus naganoensis in Escherichia coli. Ann. Microbiol, 2013; 63:289-294.

\section{How to cite this article:}

Shehata AN, Darwish DA, Masoud HMM. Extraction, Purification and Characterization of Endo-Acting Pullulanase Type I from White Edible Mushrooms. J App Pharm Sci, 2016; 6 (01): 147-152. 